\title{
An Innovative Approach to Using the Learning Management System in High School
}

\author{
Maureen Wainwright \\ Ottawa Catholic School Board, Canada
}

\begin{abstract}
In 2007, I was assigned to an overlay teaching position and given the task of delivering commercially produced Desire2Learn Ministry of Education vetted high school credit courses to atrisk students within the Ottawa Catholic School Board's various high schools. Courses were originally slated to be delivered with the student and teacher separated by distance and time. Due to the perception at that time that most students who were enrolled in on-line courses were struggling and/or failing to complete them - the idea of supported on-line learning was born. The inception of the Virtual Achievement Centre's supported online learning program and its expansion over the last five years is presented here. Challenges and successes are discussed under Lessons Learnt. Our experiences are compared with scenarios that are presently being published in academic and popular literature. Suggestions for future research projects are also given.
\end{abstract}

\section{Introduction}

On-line / e-learning is welcomed by many as a new and exciting course delivery option. Students can, in their own time and space, accumulate high school credits as well as develop valuable skills that will enhance their success in both the postsecondary sphere and/or the awaiting world of work. In 2007 however, after I had been assigned to my school board's newly created position of Virtual Achievement Centre (On-line Course) Teacher, I was informed that a school board in southern Ontario had found that only fifteen percent of students that started their on-line courses successfully completed them. Furthermore, it appeared that the only students that were having positive E-learning experiences were those that were taking "enrichment" courses. Our board had not hired me to work with gifted students; actually it was quite the opposite. I was to work with students who were working in our school's "Achievement Centres" and/or who had contact with their schools' Student Success programs. A student would have contact with either of these two programs if they were at-risk of not successfully completing their credits (courses) and/or dropping out and not graduating.

\section{Program Inception}

Prior to taking the Virtual Achievement Teacher position, I had worked as a resource (special education) teacher and as such I held two deeply ingrained convictions about teaching: it is immoral to set students up for failure and students, when supported, are capable of doing pretty much anything. These convictions forced me to make an early adjustment to the program to include face-toface support which had not been included in the original model. My work with students would start with an orientation to Desire2Learn (D2L) Learning Management System (LMS) which would be followed by weekly school visits to provide face-to-face support.

In the weeks that followed, I spent my time visiting schools - introducing myself to the Student Success, Achievement Centre and Guidance Teachers (in-school academic and social support for students), explaining the mandate of the new program and how it could benefit their students. I was not received with open arms. As one department head said quite forcefully, "I was skeptical ... there is ample evidence to support my skepticism." I asked them to give the program a try and said that if it didn't help their students that we would either amend things and/or I would respect their decision not to participate in the program.

A few weeks later, I had an opportunity to make a presentation to the Student Success Teachers and their supervisor. I told them that I would visit the 
students who would be taking courses with me once a week. Initial visits would be spent "orientating" the students - showing them how to use the D2L and assigning their first unit of work (approximately five to seven lessons/activities). The following week I would return with their corrected work, we would review it and then, if they were ready, I would assign more work. Teachers seemed amenable to at least entertaining the idea that I could be "trusted" with some of their students and so we were set to begin.

After getting the schools on-board, my next task was to review the course materials available on D2L, choose the most appropriate activities and create course outlines. By in large I found the courses were 'over-written', which made it difficult because many of the students that I was working with were not strong readers.

Almost all of my trepidations fell away once I was in the schools and actually had students in front of me. These were "my" students and I was responsible for helping them earn their credits. In Ontario, a student requires 30 credits to graduate. Eight credits are usually taken in grades 9, 10 and 11. Students will take between six and eight credits in their final, grade 12, year. Almost all of the students that first year were behind in their credits. Some were eligible for extra, "credit recovery" work that would enable them to earn a credit that they had originally not completed successfully.

Because we were trying to promote the program that first year, we purposely tried to be "all-things to all people". We offered courses at all grades, levels and in all subject areas. Over the course of the year I facilitated 24 different courses.

I wasn't as worried about the content of the courses even though it was for the most part new. What terrified me was the computers. Most of the students had very little computer experience, even less than me. Somehow we muddled through.

\section{The Program in Action}

When I met with my principal, he told me that each school would be given 4 "seats" in the Virtual Achievement Centre. There would be continuous intake: when one person finished, the next could start. Students could do credit recovery work or work towards full credits.

It was his belief that all students could benefit from an e-learning experience and it was a cost effective delivery method.

Guidance, SST, and Achievement Centre Teachers, (occasionally Vice-Principal/Principals) would recommend students at their schools that would benefit from working through courses with an online support teacher. The student's name is given to the support teacher who gives it to her office administrator. Their name is entered into D2L and a profile for the student is created.

I divided the board into Geographical Regions, and set up a schedule were I visited 2-4 schools per day. School hours, student timetables (co-op placement, etc.) dictated my schedule. My goal was to see all my students once a week. That first year, the students who took courses with me more or less set their own pace. Course workload is determined collegially - with the student, online support teacher, and school support staff. I saw the D2L courses as a 'vehicle' for the students to access curriculum. Once the student and I agreed to work through the credit this way - we agreed to participate in this activity as partners.

Often times the student needs a specific course. (e.g., they have failed a compulsory credit) or maybe it was a credit that needed to be recovered. Those courses are prescribed. But sometimes if it is an elective that they need, a decision about what course the student will take is be made by the student and the support teacher when they first met. This process creates a sense of autonomy - which is needed when trying to empower students.

I would then set up an orientation visit for the student. This initial meeting takes 30 minutes: approximately 15 minutes to orientate the students on the D2L Learning Management System and then 15 minutes to review the first unit of assigned work.

Subsequent meetings take 15 to 20 minutes to go through assignments submitted the previous week and to review the next week's work. I print off the student's assignments the night before I am to see them, correct them, give them back and review them with the students. Work is given in units that we review together; this ensures that the student and the teacher have a good idea of what the expectations are and allows the student time to clarify any instructions that may be confusing. Most of the D2L courses (even the Essential courses) presume a significant amount of literacy which not all my students possess. Going through the work together helps avoid confusion when they are on their own later in the week.

Additional support included phone calls home and/or emails to parents were made by either the in-school support staff and/or myself. Weekly visits were pre-arranged but often re-arranged to accommodate unexpected changes in my students' schedules.

Students were expected to submit assignments on a weekly basis. They did this by submitting 
assignments to dropboxes and as attachment to emails that they sent to the teacher. All questions sent in the form of emails and pages were answered within a 24 hour window.

Occasionally, when there were technical problems, hand-written assignments were accepted. When these circumstances were prolonged students were encouraged to use computers in their home school's library and/or the public library. I was available after school, before school and at lunch to ensure students had adequate supervision in library settings, etc.

My principal's belief was that students attending post-secondary institutions or work would all eventually encounter on-line courses. While it was not a specific goal of the program, the fact that students were acquiring on-line learning skills is an obvious bonus.

The students who took courses that first year were varied. A lot of students had full timetables and needed to take a fifth and often sixth credit to graduate. Some students had failed either the half credit Civics or Careers course and as such caused themselves and their guidance counselors a host of scheduling timetabling issues. Students sometimes had limited options due to their co-op placements or focus programs. Some students in the program were elite athletes and were training during school time. A few students had behavioral / social / emotional adjustment issues that necessitated working in alternative settings /arrangements. Students had credit recovery work to do. They had failed (sometimes several times) a compulsory course and needed to try something different. Students were in the wrong course 'level'; they would have been successful if they took the course at a different level. Students needed different credits, sometimes at different levels to pursue new pathways. Some Grade 12 students were looking for a sixth or seventh credit that was not offered at their school to ensure that they would have the required average to proceed with post-secondary studies.

The first two years, 332 students enrolled in courses and 318 successfully completed their courses. During those years, over a third of all my students went on to take another D2L course. They learnt the basic mechanics of the LMS and had the confidence (if needed) to take a second course.

Other highlights of those years included being asked to speak at CESBA (Ontario Association of Adult and Continuing Education School Board Administrators) in Toronto and at the inaugural SeLCO (Symposium for e-Learning in Eastern Ontario) Conference.

\section{The Program Expands}

In the fall of 2010, Michelle Frenette joined the Virtual Achievement Centre Team. She was responsible for Math, Science, Geography and Computer Science Courses. With this addition, schools were given seven seats; three with Michelle and four with me. Due to her expertise, Michelle added Academic level Math courses at all four grade levels and Grade 12 Chemistry. Schools were very happy with the addition of these courses.

That year we also implemented exams for all courses. Previously, final exams were not usually given. But, with the addition of Math and Science, the Virtual Achievement Centre needed exams to legitimately grant these credits. During the year, we created our own Virtual Achievement Centre report card. That year, 218 students were enrolled with us and 190 successfully completed their courses. Michelle and I presented at the $2^{\text {nd }}$ Annual Eastern Ontario SeLCO Conference. We were definitely moving from an obscure program into a more mainstream position.

In the fall of 2011, the program underwent several more changes when we hired another new teacher. Each school now had 10 seats. The new teacher was assigned the College and University Level Grade 11 and 12 English and Social Studies courses. She decided that because her students were predominately high achieving and more motivated, they only needed to see her every second week. There was a decrease in course completions that year. However, we also changed the way we documented enrolments and withdrawals. Using the new system, 253 students enrolled in courses with us and 201 received their credits.

In the fall of 2012, the English teacher we hired the year before moved to a new position. We hired a new upper year English / Social Sciences teacher. He kept the previous teacher's bi-weekly visit schedule while Michelle and I have kept our weekly schedule. Michelle feels that Math and Science necessitates weekly instruction and I feel that because so many of my students are at-risk, I need to check in with them every week. So far this year we have had 110 students enrolled in courses and 82 have been earned their credits.

\section{Literature Review}

My review of the literature on supported on-line learning was done recently in response to patterns I was noticing and questions that were arising. I was wondering if other e-learning teachers and programs had similar experiences, and if there was 
empirical data to support my position on on-line learning and the at-risk learner. Throughout my involvement with our program, I have questioned the procedures that have been put into place and have worked hard to ensure at-risk students are well-supported. The following is a list of papers, articles and books that I am happy to say have informed, added to or validated, in some way, my own practice.

In 2005, a lifelong friend and teaching colleague of mine Tom Conklin published his doctoral thesis entitled High School Students' Perception of Learning in Asynchronous Online Discussion: A Qualitative Study [1]. While Tom's thesis and my project are not closely linked, it seems that we as a board have not made that much progress. Perhaps Tom's research project was quite cutting-edge, but e-learning is not as mainstream as we had hoped. Tom collected his data from three of the same schools I currently visit. With the students I work with there seems little or no evidence of prior experience with $21^{\text {st }}$ century learning - which we are told students will need to be successful in postsecondary education and the world of work. It currently seems up to the individual teacher whether s/he incorporates this type of learning into her/his lessons.

The Lee Summit School District has produced a one page fact sheet entitled "Key Characteristics of a Successful Online Learner" [2]. It succinctly identifies the characteristics that help on-line learners experience success. I am sure that if my students had all of these characteristics they would be successful. However, most of my students have few of the characteristics from this list. They are not self-disciplined; if they were they would not be behind in credits. Many are not comfortable, at least initially, working on-line; the format intimidates them. They do not like trying new things. They often do not have great reading skills. They do not, when there is a problem, selfadvocate. They expect immediate feedback. They do not have any idea how much work the course is going to demand. They struggle with avoiding online distractions while they are working. Despite all this, they are successful! While I respectfully submit that this is a fine list, I would like to say that students can be successful even if they do not have these characteristics.

Why are they successful? I like to think that they are successful because I meet them where they are at and, as Dr. Tim Pychyl says in his Psychology Today blog article "Education is Not a Filling of a Pail, But the Lighting of a Fire" [3], I engage them. I have had the privilege of attending several of his workshops during which he spoke of both the science and art of student engagement.

In their paper, "Best practices in teaching K-12 online: Lessons learned from Michigan Virtual School teachers" [4] Meredith DiPietro and her colleagues interview sixteen veteran on-line instructors and then create a comprehensive spreadsheet of methods that have worked with their students. I was pleased to see that I use many of the suggested "best practices". They suggest using a variety of methods to communicate with students, accommodating different learning styles, building in course components that reflect the interests of the students enrolled in the course and considering the issues of student access to technology.

In his book, The Sixth Language: Learning and Living in the Internet Age, Robert K Logan [5] talks about how computers are giving rise to a new social class - the "computerate class". My belief is that those who have knowledge of computers and those who do not will be much like those who can read and those who cannot. Another divide will be created.

In her blog article "At-Risk Students Face ELearning Challenges" [6] Katie Ash highlights concrete examples of what is being done to make sure that we don't inadvertently add to this divide. Ash reports on how, at Westwood Cyber High School in Detroit, students are given computers to bring home. At the Brady Exploration School outside Denver, the school building is open from 8 a.m. to 9 p.m. so students can come in and work on their courses and get the support that they need.

In a blog entry of "The Innovative Teacher", a list of ten reasons students prefer learning on-line is given [7]. Number one is that they can sleep in, which co-incidentally, supports what Australian, Suzanne Warner and colleagues [8] are saying about adolescents' difficulty with learning in the morning. My students bear this research out. A second noteworthy reason was how students were still able to accumulate credits despite severe health issues which can affect attendance. This is also borne out in my practice.

What do teachers have to say about e-learning? Some have "jumped on the bandwagon" and are receiving it positively. In an article prepared by the professional body of teachers that I belong to, the Ontario College of Teachers [9], e-learning is purported to offer students more choices. Elearning is said to meet the needs of individuals on Individual Education Plans, those attending small or rural schools that have fewer course choices, those who have timetable conflicts, those who are elite athletes and those who are at-risk. 
Students may have more choices but are these choices in their best interest? In their article, "Research and Practice in K -12 Online Learning: A Review of Open Access Literacy" [10] Cathy Cavanagh and her colleagues conclude that empirical research data regarding on-line learning is still very limited. They state that there is an increase in enrolment in e-learning courses but that there is not a lot of research regarding how to support students in these courses. They question the current relationships and wonder what will become of students in "brick and mortar schools" and students who take only e-learning courses. Finally, they state that there is a need to examine the "quality" of the students' learning experience when they take an on-line course.

\section{Lessons Learnt}

Supported on-line learning has worked! And it has worked for a variety of students with a variety of learning needs! It has worked for at-risk and disengaged learners. It has worked for students with high anxiety and school-refusal issues. It has worked for students with Autism. It has worked for pregnant teens. It has worked for ESL students we love "google translator". It has worked with students with visual impairments - we employed "zoom" technologies. It has worked for elite athletes. It has worked for students with little or no prior computer knowledge. Those sometimes are the very students who seamlessly move on to take another course.

It seems to work for two reasons. It works because of the individualized instruction that we provide through our visits and on-going communication with our students AND the support (in its many guises) that the teachers at their schools give.

One of the things that I have learned is that the students need me to establish firm due dates. The first few years, I let them hand in things whenever they wanted. Besides the fact that my marking around mid-term reports and finals was totally out of control, I did the students no favours but letting them procrastinate. As we say, with a smile, to the students, "it's the weirdest thing that on-line courses don't do themselves." The students need the due dates. They also need you to correct their work in a timely fashion that keeps them going.

We use a multitude of communication channels. If you don't log on to the computer you don't have to worry about running into your on-line teacher. The weekly meetings help but we also call and text our students. In the beginning we left most of the home-school communication to their support teachers. We respect that they are that school's student; but, if information needs to get to their parents, we now make the phone calls. The students say they don't like it; but the message they receive is "she cares enough to bother". The kids know how busy we are, but they also know that they are our students and we want them to succeed.

Exams and more formal assessments have also helped the students. Exam reviews are given; the students know what to expect and they are not set up to be super stressful occasions. The exam though gives the courses credibility.

I have gotten more familiar over the years with the on-line course materials, and the students benefit from this. When I teach / facilitate a course for the first time, I tell them that they're my 'guinea pig'.

\section{Further Research Projects}

Students are getting their credits, which is the good news. However, there are still lots of questions.

It has been interesting over the last two years to see how the new teachers have pared down their school visits. Michelle and I still seem to believe that our students need the weekly visits. Are we right? Would the other students benefit from more visits? In some school boards, e-learning schools have centres where the students come to them. Would that work?

An assessment of the students' computer skills prior to starting the course and then an exit survey would be helpful to determine whether their skills improve or not and whether we are providing them with the secondary benefit of more computer experience or not. Further to this, if could find a way to track the students after they left us, we could attempt a longitudinal study to compare how the e-learning students manage similar postsecondary or workplace computer tasks as compared to their peers that did not have the 'benefit' of taking an e-learning course.

Quality of experience is another topic that needs to be investigated. I am told by my colleagues that on-line credit recovery learning does prepare their students for subsequent academic challenges and this is good to hear. Yet, I still wonder if the students I work with are really getting a good "quality" learning experience vs. their peers who are in-class. Often times, the students are "hard to serve" so the option of them returning to class is not there. But what about students who could manage an in-class experience if needed? We have had experiences where parents have wanted their teenager to take a course with us because they 
wanted the individualized instruction. They thought that a supported on-line experience would be more beneficial for their child than a classroom experience.

I think that we make good use of the multi-media extras that on-line learning provides but could we be doing more? Could we be providing more and better differentiate instruction as to further enhance our student's e-learning experience?

Collaboration with 'classroom' teachers is sometimes minimal; I would say that by its very nature, on-line teaching would risk teachers having even less contact. It would be interesting to study how we could promote more collaborative communities where practitioners worked to support each other with their collective student groupings.

\section{Acknowledgements}

Thank you to everyone who has been involved with the Virtual Achievement Centre program at St. Nicholas: John Karam, Mars Bottiglia, Adam Hobbins, Mary-Ellen Angel, Bev MacKillop, Dave Nash, Mary Lemoine, Michelle Deveaux and Michelle Frenette. Thank you to Tom Conklin, Natalie Wainwright, Sam Wainwright and Rory Donohoe, who helped me with the paper. True gratitude is sent to all the past and present High School Principals/Vice-Principals, Student Success, Achievement Centre and Guidance Teachers and Student Services Secretaries at the Ottawa Catholic School Board's 15 High Schools; it is only because of your support of this program and the students in it, that it has worked! And to each and every one of my students - you have taught me so much! Thank you all!

\section{References}

[1] Conklin, Thomas A. (2005). High School Students' Perception of Learning in Asynchronous Online Discussion: A Qualitative Study. Unpublished doctoral dissertation, University of Toronto.

[2] Lee's Summit School District. (2008). Key Characteristics of a Successful Online Learner. Retrieved March 26, 2009 from the World Wide Web: http://alldistrict.leesummit.k12.mo.us/r7online/Online $\% 2$ OLearners.pdf

[3] Pychyl, Timothy. (2008). Don't Delay: Understanding procrastination and how to achieve our goals. Retrieved May 6, 2010 from the World Wide Web: http://www.psychologytoday.com/blog/dontdelay/200805/education-is-not-the-filling-pail-thelighting-fire
[4] DiPietro, Meredith, Ferdig, Richard, M., Black, Erik, W., Preston, Megan. (2008). Best practices in teaching K-12 online: Lessons learned from Michigan Virtual School teachers. Journal of Interactive Online Learning, 7 (1).

[5] Logan, Robert, K. (2001). The Sixth Language: Learning a Living in the Internet Age. Toronto: Stoddart Publishing.

[6] Ash, Katie (2011). At-Risk Students Face ELearning Challenges. Retrieved October 26, 2011 from the World Wide Web: http://www.edweek.org/ew/articles/2011/08/24/01edtech -trisk.h31.html?tkn=RPUF5/

XuvAAZpyBPB906jZZtbxyshVNyTfQi\&cmp=clp-sbascd

[7] Nielson, L. (2010). 10 Reasons Students Say They Prefer Learning Online. Retrieved MONTH DATE, YEAR from the World Wide Web: February 27, 2011 http://theinnovativeeducator.blogspot.ca/2010/11/10 reasons-students-say-they-prefer.html.

[8] Warner, Suzanne, Murray, Greg, Meyer, Danny. (2008). Holiday and school-term sleep patterns of Australian adolescents. Journal of Adolescence, 31(5), 595-608.

[9] Foxman, Stuart. (2011). What happens when learning takes place at a distance? As online courses multiply in Ontario, teachers explore how they can help students succeed.

http://professionallyspeaking.oct.ca/june_2011/features/c onnected.aspx, (Access date: 6, 2011)

[10] Cavanaugh, Cathy, S. Barbour, Michael, K. Clark, Tom. (2009). Research and Practice in K-12 Online Learning: A Review of Open Access. The International Review of Research in Open and Distance Learning, (10)1. 